ISSN 2088-5415 (Print)

ISSN 2355-5777 (Online)

https://jurnal.ugm.ac.id/kawistara/index

https://doi.org/ 10.22146/kawistara.37314

JURNAL KAWISTARA

VOLUME 9

No. 1, 22 April 2019

Halaman 1-14

\title{
PERSEPSI DAN PENGELOLAAN HOMESTAY DI DESA WISATA WUKIRSARI BANTUL
}

\author{
*Devi Puspitasari \\ Program Studi Magister Kajian Pariwisata \\ Sekolah Pascasarjana Universitas Gadjah Mada \\ Heddy Shri Ahimsa-Putra \\ Departemen Antropologi Fakultas Ilmu Budaya \\ Universitas Gadjah Mada \\ Djoko Wijono \\ Program Studi Magister dan Doktor Arsitektur Fakultas Teknik, \\ Universitas Gadjah Mada \\ Submitted: 21-07-2018; Revised: 27-09-2018; Accepted: 21-02-2019

\begin{abstract}
Homestay is one of the criteria for the existence of a tourism village. Its existence as one of tourism accommodation forms is important to tourism development in tourism village. Homestay is one of a place in the tourism industry where tourist could meet the local people. The Indonesian government also creates a policy for the development of amenities (homestay). Therefore, the perception of the homestay concept becomes important for a homestay owner. After knowing its concept, the owner can manage their homestay based on the homestay management guideline. Homestay management aspects of this research are physical and environmental management, human resources, institutional aspects, data, and promotion management. Professional homestay management can be an opportunity for local people to make the tourist stay longer and enjoy the natural view as well as the culture in tourism village. The aim of this research is to determine the perceptions of homestay and its management at Wukirsari Tourism Village. The benefit of this research is to provide more references regarding tourism studies, especially on homestay management. The methods used in this study are observation, interviews, and documentation. The result reveals that owners know the concept of homestay, but they lack knowledge of management. Training about homestay and its management is needed for the owner in Wukirsari tourism village.
\end{abstract}

Keywords: Homestay; Management; Perception.

\section{ABSTRAK}

Homestay merupakan salah satu kriteria dari adanya desa wisata. Homestay sebagai salah satu bentuk akomodasi pariwisata berperan cukup penting dalam upaya pengembangan pariwisata di desa wisata. Homestay merupakan salah satu produk dari industri pariwisata di mana wisatawan dapat bertemu

*Corresponding author: puspitasaridv08@gmail.com.

Copyright@ 2019 THE AUTHOR (S). This article is distributed under a Creative Commons Attribution-Share Alike 4.0 International license. Jurnal Kawistara is published by the Graduate School of Universitas Gadjah Mada. 
langsung dengan warga setempat. Pemerintah Indonesia juga telah membuat kebijakan terkait pengembangan amenitas (homestay). Persepsi tentang konsep homestay menjadi salah satu hal penting bagi pemilik homestay. Setelah memahami konsep homestay, pemilik dapat mengelola homestay sesuai dengan pedoman pengelolaan homestay. Aspek pengelolaan homestay antara lain pengelolaan fisik dan lingkungan, sumber daya manusia, kelembagaan, data, dan promosi. Pengelolaan homestay secara profesional dapat menjadi peluang bagi masyarakat untuk menarik wisatawan tinggal lebih lama untuk menikmati kekayaan alam dan budaya di Desa Wisata. Tujuan penelitian ini adalah untuk mengetahui persepsi dan pengelolaan homestay di desa wisata Wukirsari. Manfaat penelitian ini adalah untuk menambah referensi dalam kajian pariwisata khusunya mengenai pengelolaan homestay. Metode penelitian yang digunakan adalah observasi, wawancara, dan dokumentasi. Penelitian ini mengungkap persepsi homestay sudah diketahui pemilik, tetapi masih ada kekurangan dalam pengelolaan homestay oleh pengelola di desa wisata Wukirsari. Saran dari penulis adalah perlunya pelatihan bagi pemilik homestay tentang homestay dan pengelolaannya.

\section{Kata Kunci: Homestay; Pengelolaan; Persepsi.}

\section{PENGANTAR}

Persepsi masyarakat dalam hal ini pemilik homestay terhadap homestay menjadi perhatian peneliti. Persepsi pemilik homestay tentang homestay dapat beragam, baik positif maupun negatif. Persepsi pemilik homestay tersebut diasumsikan dapat mempengaruhi pola mereka dalam mengelola homestay. Persepsi adalah proses menyeleksi, menginterpretasi, menganalisis, dan mengintegrasikan rangsangan yang dibawa oleh rangsangan organ dan otak Feldman (2009).

Memiliki usaha homestay tentu membutuhkan pengelolaan homestay yang baik. Rumah yang biasanya merupakan area privat, ketika dimanfaatkan sebagai homestay, sebagian berubah menjadi area publik. Pemilik rumah mulai bersikap terbuka terhadap orang lain (wisatawan) yang menginap di rumahnya. Pengelolaan homestay dengan demikian menjadi salah satu hal penting agar wisatawan yang menginap merasa betah seperti di rumah sendiri, sehingga dapat tinggal lebih lama di desa wisata. Adanya pengelolaan homestay juga dapat menjadi sarana untuk mempromosikan daya tarik wisata dan aktivitas yang ada di Desa Wisata Wukirsari. Pengelolaan homestay pada akhirnya akan bermanfaat dalam pengembangan pariwisata di desa wisata.

Pengelolaan homestay diperlukan untuk memenuhi serta meningkatkan lama tinggal wisatawan atau length of stay (LoS), juga meningkatkan kepuasan wisatawan dalam menikmati daya tarik wisata di desa wisata. Pengelolaan atau management adalah pemanfaatan sumber daya organisasi, terutama sumber daya manusia yang merupakan aset paling berharga, untuk menciptakan jasa, keluaran atau produk yang sejalan dengan apa yang diminta wisatawan sebagai konsumen (Page, 2007). Konsep lain dari pengelolaan adalah melakukan sesuatu secara kompeten, baik mengoordinasi maupun mengawasi aktivitas pekerjaan orang lain sehingga dapat selesai secara efektif dan efisien (Robbins dan Coulter, 2009). Proses dasar pengelolaan adalah planning, organizing, leading, and controlling. Pengelolaan homestay berarti perencanaan, pengorganisasian, pengarahan, dan pengawasan homestay yang bertujuan untuk meningkatkan kualitas pengelolaan homestay secara efektif dan efisien, sehingga tercipta kesejahteraan warga masyarakat di Desa Wisata Wukirsari. Pengelolaan homestay membutuhkan adanya komunikasi dan koordinasi yang baik antar semua pihak.

Pengelolaan homestay dalam penelitian ini melihat mengenai cara mengurus atau menjalankan homestay yang dilakukan pemilik homestay terkait aspek:

1. Fisik dan lingkungan mengacu $\mathrm{Hu}$, Wang, dan Wang (2012), Tyas (2009), dan AhimsaPutra (2011). Pengelolaan aspek fisik dan lingkungan, akan dilihat pada beberapa hal, seperti bangunan homestay, kebersihan dan/ atau sanitasi, dan fasilitas-fasilitas lainnya.

2. Sumber Daya Manusia, Kelembagaan, dan Data mengacu Hu, Wang, dan Wang (2012) dan ASEAN Secretariat (2016). Pengelolaan aspek SDM dan Kelembagaan dilihat dari ada atau tidak karyawan yang membantu dalam pengelolaan homestay, ada/tidaknya nama homestay, ada/tidaknya kelembagaan 
yang khusus menangani homestay, mengikuti pelatihan/studi banding, perencanaan homestay, data pemilik homestay, data homestay, data keuangan/administrasi, data wisatawan.

3. Promosi mengacu Hu, Wang, dan Wang (2012) dan ASEAN Sekretariat (2016). Pengelolaan homestay pada aspek promosi dilihat dari cara-cara yang sudah dilakukan oleh pemilik homestay untuk mempromosikan homestay diteliti, apakah melalui website, brosur, media sosial, word of mouth atau getok tular, serta apakah melalui kerja sama dengan pihak lain.

Pengelolaan homestay secara profesional dapat menjadi peluang bagi masyarakat desa wisata untuk menarik wisatawan tinggal dan menikmati kekayaan alam dan budaya yang dimilikinya. Menurut Ibrahim dan Razzaq (2010), kesuksesan program homestay dipengaruhi oleh adanya partisipasi dan komitmen masyarakat, pemerintah, dan pihak swasta. Penelitian ini bertujuan untuk mengetahui persepsi pemilik homestay tentang homestay dan keterkaitannya dengan pengelolaan homestay di Desa Wisata Wukirsari.

Lokasi penelitian berada di Desa Wisata Wukirsari, tepatnya di Dusun Cengkehan, Dusun Giriloyo, dan Dusun Karangkulon, Desa Wukirsari, Kecamatan Imogiri, Kabupaten Bantul. Hadir sebagai sentra industri kerajinan utama berupa batik tulis dan didukung dengan kerajinan lain seperti kerajinan kulit, rotan, sutera, dan bambu. Desa Wisata Wukirsari juga memiliki keindahan alam yang masih alami.

Masyarakat di Desa Wisata Wukirsari sebagian besar merupakan pengrajin batik tulis yang sudah mewarisi keahlian membatik secara turun temurun. Batik tulis sebagai salah satu warisan budaya dunia dapat dipelajari dan dilestarikan oleh wisatawan dengan mempelajarinya langsung di desa wisata. Wisatawan dapat menginap di homestay, selain mempelajari proses pembuatan batik tulis, tetapi dapat juga mempelajari cara hidup masyarakat pengrajin batik tulis. Pada tahun 2018, terdapat 29 homestay di Desa Wisata Wukirsari, yang terdiri dari 12 homestay pasif dan 17 homestay aktif. Pada penelitian ini difokuskan pada homestay aktif yang ada di Desa Wisata Wukirsari.

Metode penelitian yang digunakan dalam penelitian ini adalah observasi, wawancara kepada pemilik homestay (terutama homestay aktif), warga masyarakat, dan pengelola desa wisata. Selain itu juga dilakukan dokumentasi atau penelusuran data-data terkait dengan homestay melalui buku, jurnal, internet, dan laporan-laporan penelitian. Pemilihan informan dilakukan dengan cara Purpossive Sampling, di mana informan dipilih dengan pertimbangan tertentu (Sugiyono, 2016). Analisis data yang digunakan adalah model interaktif (Huberman dan Miles dalam Denzin dan Lincoln, 2009). Analisis data tersebut terdiri dari tiga komponen yang saling terkait, yaitu reduksi data, penyajian data, dan kesimpulan.

Proses pemilihan data dari data kasar (raw data) yang diperoleh dari catatan lapangan maupun hasil wawancara, untuk disederhanakan, dilakukan abstraksi dan transformasi sesuai dengan pertanyaan penelitian. Tahap analisis setelah reduksi data, di mana informasi yang dikumpulkan dari penelitian di lapangan, disusun sehingga memungkinkan diambil kesimpulan dan tindakan. Penyajian data tersebut dapat berupa teks, tabel, grafik, diagram, bagan, dan/atau peta. Penyajian data mempermudah untuk memahami kondisi di lapangan dan merencanakan kerja selanjutnya atas apa yang telah dipahami. Data dianalisis menggunakan analisis deskriptif. Pada tahap akhir, peneliti melakukan interpretasi atau memberi makna atas data-data yang telah disajikan.

\section{PEMBAHASAN}

Homestay muncul berdasarkan inisiatif warga masyarakat di desa wisata dan pengaruh dari luar warga masyarakat. Relawan pascagempa, peneliti, dan/atau wisatawan yang ingin mempelajari batik menjadi faktor munculnya homestay di desa wisata. Mereka menginap selama minimal satu hari di rumah warga masyarakat setempat. Mereka berinteraksi dengan pemilik rumah. 
Tabel 1.

Status Homestay per April 2018

\begin{tabular}{llllll}
\hline No. & Status Homestay & Dusun Cengkehan & Dusun Giriloyo & Dusun Karang Kulon & Jumlah \\
\hline 1 & Aktif & 6 & 4 & 7 & 17 \\
2 & Pasif & 1 & 6 & 5 & 12 \\
\hline \multicolumn{2}{l}{ Total } & 7 & 10 & 12 & 29 \\
\hline
\end{tabular}

Berdasarkan Tabel 1 dapat diketahui bahwa terdapat 29 homestay di Desa Wisata Wukirsari, terdiri dari 12 homestay pasif dan 17 homestay aktif. Homestay aktif adalah homestay yang saat ini digunakan oleh warga masyarakat untuk menerima wisatawan menginap, berdasarkan kesediaan dan kesiapan pemilik homestay. Sementara homestay pasif adalah warga masyarakat yang pernah memiliki homestay atau rumahnya pernah digunakan untuk menginap wisatawan, tetapi saat ini sudah tidak difungsikan lagi sebagai homestay. Pemilik homestay pasif tidak mau lagi membuka usaha homestay karena alih fungsi ruang dan/ atau menganggap rumahnya tidak layak dijadikan homestay. Kenyataan yang dijumpai di lapangan adalah total kamar homestay aktif di desa wisata Wukirsari sebanyak 40 kamar dengan kapasitas menerima wisatawan 102 orang.

Tabel 2.

Usia Pemilik Homestay Aktif

\begin{tabular}{llllll}
\hline No. & Jenis Kelamin & Usia 20-40 tahun & Usia 41-60 tahun & Usia $>$ 61 tahun & Jumlah \\
\hline 1 & Laki-laki & 1 & 6 & 2 & 9 \\
2 & Perempuan & 1 & 6 & 1 & 8 \\
\hline \multicolumn{2}{l}{ Total } & 2 & 12 & 3 & 17 \\
\hline
\end{tabular}

Sumber: Data Primer, 2018

Informan, pemilik homestay aktif, terdiri dari 9 (sembilan) orang laki-laki dan 8 (delapan) orang perempuan dengan usia yang beragam. Mayoritas pemilik homestay berusia produktif, yaitu usia 41-60 tahun. Hal ini diasumsikan bahwa pemilik homestay masih mampu untuk mengelola homestay yang mereka miliki. Pemilik homestay yang beruisa 20-40 tahun terdiri dari dua orang dan pemilik homestay yang sudah berusia lanjut, yaitu di atas 61 tahun terdiri dari tiga orang (Tabel 2).

Latar belakang pendidikan pemilik homestay aktif pun beragam. Mulai dari tingkat pendidikan SMP/MTs, SMA/MA, sarjana (D3/S1). Tabel 3 menginformasikan latar pendidikan pemilik homestay aktif di Desa Wisata Wukirsari.

Tabel 3.

Latar Belakang Pendidikan Pemilik Homestay Aktif

\begin{tabular}{|c|c|c|c|c|c|}
\hline No. & Jenis Kelamin & SMP/MTs & SMA/MA & D3/S1 & Jumlah \\
\hline 1 & Laki-laki & 1 & 5 & 3 & 9 \\
\hline 2 & Perempuan & 4 & 2 & 2 & 8 \\
\hline Tota & & 5 & 7 & 5 & 17 \\
\hline
\end{tabular}

Sumber: Data Primer, 2018

Tabel 3 menunjukkan bahwa latar belakang pendidikan pemilik homestay mayoritas adalah SMA/MA yaitu sebanyak 7 orang. Pemilik homestay yang berlatar belakang $\mathrm{SMP} / \mathrm{MTs}$ sebanyak 5 orang dan yang sudah mencapai tingkat pendidikan D3/S1 sebanyak 5 orang. Pemilik homestay dengan demikian sudah pernah menempuh pendidikan minimal SMP/MTs, sehingga diasumsikan mereka mudah menerima informasi, dan mau untuk 
mengembangkan wawasan serta menambah pengetahuan.

Arsitektur homestay yang ada di desa wisata Wukirsari terdiri dari arsitektur kontemporer dan kombinasi arsitektur tradisional dan kontemporer. Arsitektur tradisional berangkat dari kata tradisi yang mengacu pada prinsip kegiatan pada satu babak waktu yang secara konsisten berulang dan membentuk sebentuk koherensi artistik yang cerdas, baik di masa lalu ataupun kini (Widiastuti, 2014). Arsitektur tradisional yang memiliki gaya lokal seperti misalnya bentuk rumah joglo, limasan, atau kampung yang masih dapat dijumpai di masa kini.

Arsitektur kontemporer adalah suatu gaya aliran arsitektur yang muncul pada akhir abad XX yang mencirikan kebebasan berekspresi dan keinginan untuk menampilkan sesuatu yang berbeda dari komunitas di sekitarnya yang merupakan aliran baru atau penggabungan dari beberapa aliran arsitektur (Gunawan, D.E.K dan Prijadi, R, 2011). Lebih lanjut diuraikan bahwa ciri dari arsitektur kontemporer antara lain ekspresi bangunan

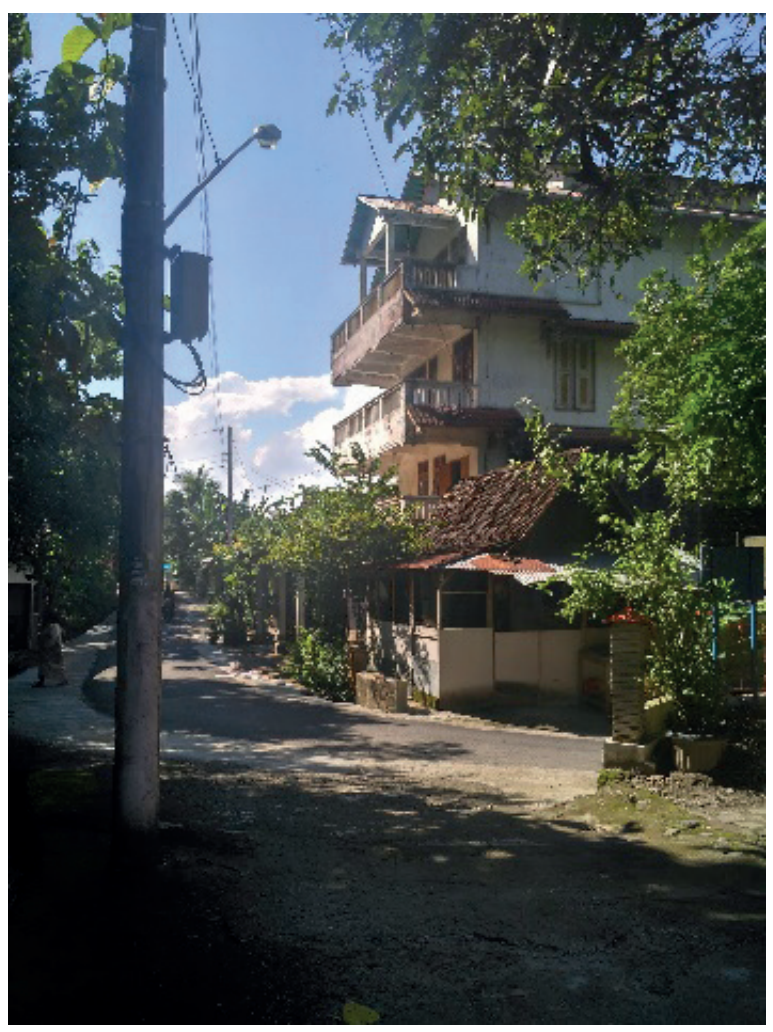

Gambar 1. Homestay di Dusun Giriloyo Sumber: Dok Foto Peneliti, 2018 bersifat subyektif, kontras dengan lingkungan sekitar, dan memiliki bentuk yang sederhana, tetapi berkesan kuat. Hal tersebut dapat ditemukan di beberapa homestay aktif yang ada di Desa Wisata Wukirsari.

Sementara arsitektur kombinasi tradisional dan kontemporer adalah arsitektur yang mengombinasikan kedua jenis arsitektur tersebut. Misalkan pada sebagian rumahnya terdapat bangunan dengan arsitektur kontemporer, dan pada bagian lain seperti atap menggunakan gaya arsitektur tradisional (seperti atap limasan, joglo, atau kampung).

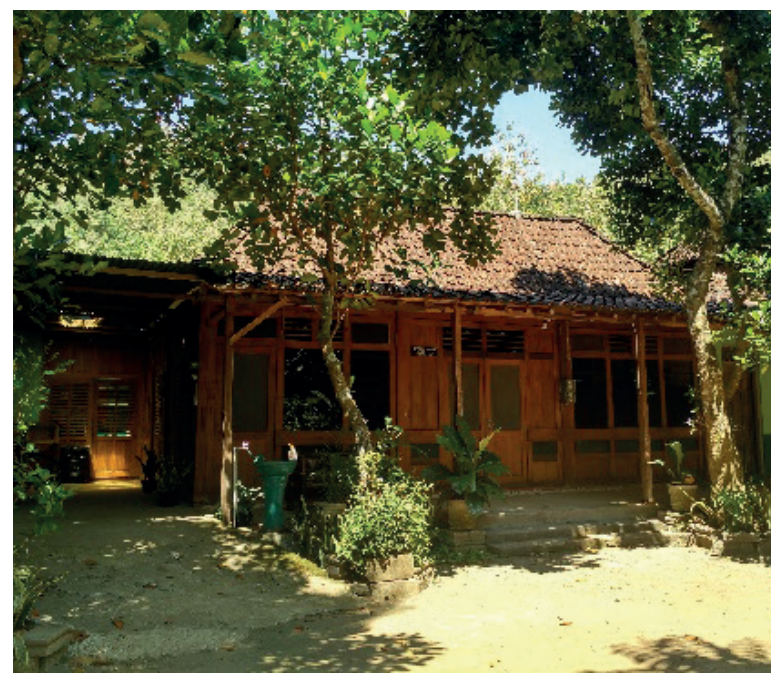

Gambar 2. Homestay di Dusun Karang Kulon Sumber: Dok Foto Peneliti, 2018

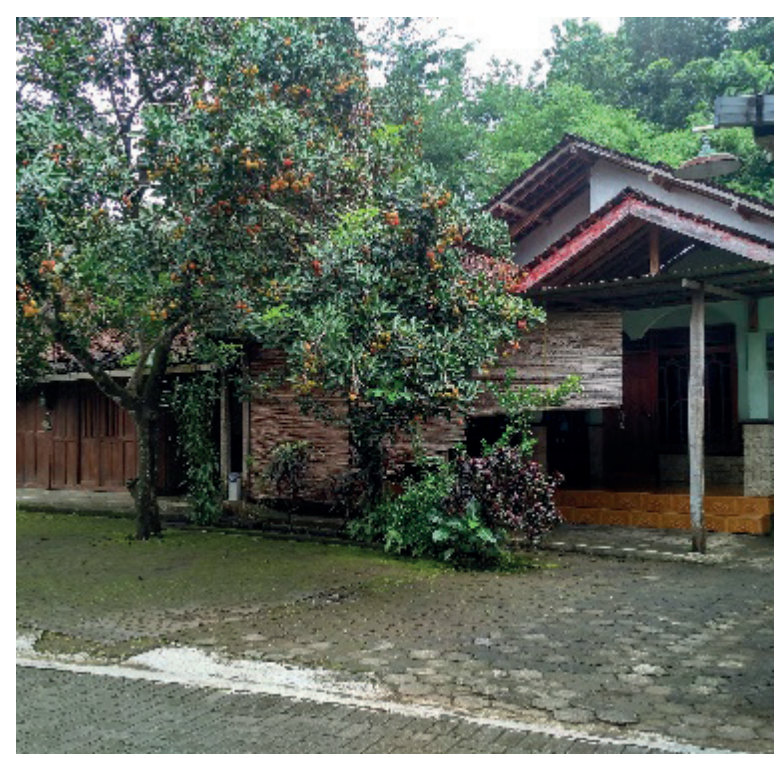

Gambar 3. Homestay di Dusun Cengkehan Sumber: Dok Foto Peneliti, 2018 
Tabel 4.

Arsitektur Homestay Aktif di Desa Wisata Wukirsari

\begin{tabular}{lll}
\hline \multicolumn{1}{c}{ Arsitektur } & \multicolumn{1}{c}{ Jumlah Homestay } \\
\hline Tradisional & 0 & \\
Kombinasi Tradisional dan Kontemporer & 8 & \\
Kontemporer & 9 & \\
\hline Jumlah Total & 17 & \\
\hline
\end{tabular}

Sumber: Data Primer, 2018

Rumah yang dikelola sebagai homestay mayoritas adalah kombinasi arsitektur tradisional dan kontemporer dan arsitektur kontemporer. Homestay dengan arsitektur tradisional, jarang ditemukan. Kombinasi arsitektur tradisional dan kontemporer menjadi salah satu upaya untuk menarik wisatawan menginap di desa wisata. Pemilik homestay masih berusaha untuk melestarikan arsitektur tradisional, meskipun sudah dikombinasi dengan arsitektur kontemporer.

Sejarah homestay di Desa Wisata Wukirsari dimulai sejak tahun 1997, di mana ada mahasiswa KKN yang menginap di rumah tokoh masyarakat. Sektar tahun 2009, ada mahasiswa KKN dari perguruan tinggi di Yogyakarta yang menginap di rumah ketua kelompok batik, dan memberikan pelatihan kepada warga masyarakat. Istilah homestay kemudian mulai populer pada tahun 2012, seiring dengan adanya event di Desa Wisata Wukirsari. Pada acara tersebut sekitar 70 orang wisatawan asing menginap di homestay. Jumlah wisatawan yang menginap di homestay dari tahun 1997-2017 sebanyak 1.298 orang wisatawan. Sementara jumlah wisatawan yang menginap di homestay aktif sebanyak 984 orang.

Tabel 5 .

Jumlah Kunjungan Wisatawan ke Homestay Aktif di Desa Wisata Wukirsari Tahun 1997-2017

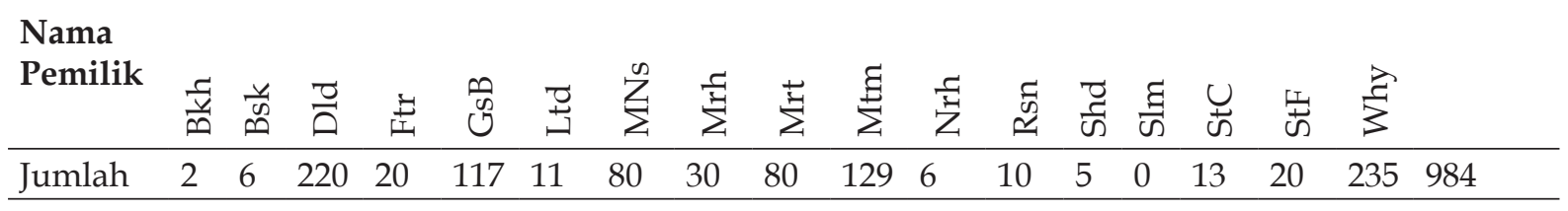

Sumber: Data Primer, 2018

Jumlah kunjungan wisatawan ke homestay aktif mengalami perbedaan yang cukup signifikan. Jumlah kunjungan wisatawan yang tinggi biasanya ada di rumah tokoh masyarakat, seperti kepala dusun. Rumah kepala dusun seringkali digunankan untuk tempat menginap pelajar, mahasiswa, atau wisatawan. Rumah mereka ada yang digunakan untuk tempat latihan membatik sekaligus menginap. Jumlah kunjungan wisatawan yang rendah, bahkan tidak pernah dikunjungi wisatawan biasanya terjadi di rumah warga.
Desa Wisata Wukirsari kemudian berkembang dan banyak dikunjungi wisatawan, sehingganmembuat warga masyarakat sedikit demi sedikit memperbaiki, membersihkan rumahnya untuk menyediakan alternatif akomodasi bagi wisatawan yang ingin menginap dan menikmati suasana pedesaan. Wisatawan yang akan menginap harus mengajukan izin ke pengelola desa wisata, kepala dukuh, dan/atau Ketua RT, setelah itu dilakukan rapat pemilihan untuk menentukan warga yang siap dan bersedia menerima serta melayani wisatawan. 


\section{Persepsi Pemilik Homestay Aktif terhadap Konsep Homestay}

Pemilik homestay mempunyai persepsi yang beragam. Sebanyak 16 orang tahu tentang homestay, sementara satu orang yang belum tahu istilah homestay sebelum dijelaskan pengertian homestay. Mayoritas pemilik homestay aktif sudah mengetahui homestay. Beragam persepsi disampaikan oleh para pemilik homestay aktif di desa wisata Wukirsari. Mereka menerima homestay, bersedia mengelola homestay, dan mendapat keuntungan yang diperoleh dari kepemilikan homestay.

Tabel 6

Persepsi Pemilik Homestay terhadap Konsep Homestay

\begin{tabular}{|c|c|c|}
\hline \multicolumn{2}{|c|}{$\begin{array}{c}\text { Persepsi terhadap Konsep } \\
\text { Homestay }\end{array}$} & \multirow{2}{*}{$\begin{array}{c}\text { Jumlah Pemilik } \\
\text { Homestay }\end{array}$} \\
\hline Tahu & Tidak Tahu & \\
\hline 16 & 1 & 17 \\
\hline
\end{tabular}

Salah satu pemilik homestay yang mengetahui tentang konsep homestay, disampaikan oleh Mtm,

"Konsep homestay kan menyatu dengan keluarga, jadi orang menginap itu tahu kebiasaan [pemilik homestay]. Menurut saya juga perlu tapi ya tergantung sih. Kalau ingin meningkatkan pendapatan, ingin dikenal, ingin memperluas wawasan itu memang menurut saya, kita harus terbuka. Dan kalau senang di bidang itu, menurut saya bagus juga karena efeknya juga tidak sebatas homestay itu aja to, nanti kan bisa untuk yang lain, jadi lebih kenal banyak orang."

Menurut Mtm, homestay adalah tempat menginap wisatawan di rumah warga masyarakat. Wisatawan dengan demikian mendapatkan pengalaman tinggal bersama warga lokal, mengetahui kebiasaan seharihari warga masyarakat. Warga masyarakat juga dapat bersikap terbuka dengan adanya wisatawan yang menginap di rumahnya. Warga masyarakat juga dapat memperluas wawasan dan mengenal banyak orang. Pendapat lain disampaikan oleh Ltd, yang mengetahui konsep homestay,
"Ya Sebenarnya konsep homestay itu memang harus ada yang serumah, jadi kalau saya membangun di sana terus saya gunakan untuk tempat menginap itu memang tidak pas. Jadi, homestay itu memang paling enak itu ada keakraban antara pemilik rumah dan tamu, sehingga betul-betul mereka itu merasakan hidup di kampung seperti ini, justru malah mengikuti di rumah. Makanya tidak perlu diada-adakan, makannya biasanya apa, sayur dan sambal ya apa adanya. Jadi, sebenarnya kalau saya mau siapkan homestay di sana, paling tidak kalau ada tamu harus ditemani, misal saya mau mendirikan disana kalau ada tamu disana saya harus menginap disana, nanti kita ajak masak bareng. Biasanya kalau yang tinggal disini kita ajak bantu-bantu masak. Menurut saya yang paling ideal seperti itu, menyatu dengan keluarga."

Ltd menyampaikan bahwa homestay adalah tempat menginap wisatawan di rumah warga, sehingga ada keakraban antara pemilik rumah dengan wisatawan. Wisatawan dapat merasakan cara hidup di desa dan mengikuti kebiasaan yang ada di desa. Wisatawan dapat masak dan menikmati makanan lokal, sehingga dapat menyatu dengan keluarga. Persepsi Ltd tentang homestay tersebut termasuk ke dalam persepsi positif.

Menurut $\mathrm{NrH}$, "keberadaan homestay dapat membantu pendapatan dari keluarga sendiri. Cuma kita ya ngopeni omahe dhewe oleh gaji". Homestay dengan demikian dimaknai dengan merawat rumah sendiri dan mendapat keuntungan, tanpa harus keluar dari rumah. Sementara menurut GsB, "homestay itu tetap dibutuhkan dalam satu keluarga, minimal kalau keluarga itu ada tamu bisa ada kamar yang tersedia untuk menginap. Kalau ada wisatawan datang, desa wisata sudah siap menerima kehadiran wisatawan yang akan menginap". Desa wisata harus menyediakan homestay, yaitu rumah warga yang disewakan untuk menginap wisatawan. Apabila ada wisatawan yang ingin menikmati Desa Wisata Wukirsari dan sampai larut malam, wisatawan tidak perlu jauh-jauh mencari penginapan. Wisatawan bisa menyewa penginapan yaitu di rumah warga. Seperti yang dituturkan oleh Rsn, bahwa homestay itu istilahnya meringankan mereka yang seumpama menikmati daerah 
sini, kemalaman, dan tidak usah jauh-jauh mencari penginapan.

Terdapat satu informan yang menyatakan tidak tahu mengenai konsep homestay. Ketika diwawancara tentang rumahnya yang menjadi homestay, Slm menanyakan, "homestay itu apa?"

Hal tersebut dapat diartikan bahwa istilah homestay belum diketahui oleh pemilik homestay.

\section{Pengetahuan tentang Pengelolaan}

Pengetahuan pemilik homestay tentang pengelolaan homestay dilihat pada beberapa aspek, antara lain pengelolaan fisik dan lingkungan, pegelolaan SDM, kelembagaan, data, dan promosi. Pengetahuan tentang pengelolaan fisik dan lingkungan yang dimiliki oleh pemilik homestay mayoritas sudah baik. Pengelolaan fisik dan lingkungan dilihat pada pengelolaan kebersihan dan/atau sanitasi dan ketersediaan fasilitas di dalam kamar tidur homestay. Kondisi baik adalah rutin dibersihkan, kondisi cukup baik adalah yang jarang dibersihkan, sementara kondisi kurang baik adalah yang tidak pernah dibersihkan. Kondisi kamar yang baik adalah kamar yang rutin dibersihkan dan selalu rapi. Sementara kamar dengan kondisi cukup baik adalah kamar yang kadang-kadang dibersihkan dan tidak selalu dalam kondisi rapi. Sementara kondisi kamar mandi yang baik adalah yang bersih dan memiliki penerangan yang cukup. Kondisi kamar mandi yang cukup baik yaitu kamar mandi yang jarang dibersihkan dan penerangannya kurang. Pengelolaan limbah padat yang kurang baik berarti sampah dibuang sembarangan. dapur, lingkungan, dan pengelolaan limbah yang baik. Selain itu, ada tiga orang pemilik homestay yang kondisi pengelolaan limbah padat masih kurang baik. Terdapat pemilik homestay yang belum mengelola limbah padat dengan baik, yaitu dengan membuang sampah di sungai. Menurut penuturan Shd,

\section{"Sementara karena di hutan, kalau sampah saya banyak dan hanya dibuang ke sungai, beberapa dikubur"}

GsB mengungkapkan bahwa keranjang sampah disediakan di dalam kamar homestay, sementara di luar kamar digunakan bekas karung semen untuk pembuangan sampah. Lubang untuk pembuangan sampah juga dibuat di belakang rumah.

\section{"Sampah yang ada di dalam kita sediakan tempat sampah, keranjang tertutup. Untuk pembuangan sampah, dulu saya memakai sak, saya sendirikan di belakang atau ya lubang sampah itu."}

Pengelolaan fisik dan lingkungan dengan demikian sedikit banyak telah diketahui oleh pemilik homestay. Mereka menyediakan fasilitas dan mengelola kebersihan dan/atau sanitasi dengan baik sesuai dengan pengetahuan dan kemampuan mereka. Beberapa fasilitas yang tersedia di dalam kamar tidur homestay, dapat diasumsikan bahwa pemilik homestay sudah memiliki pengetahuan tentang apa saja yang sebaiknya tersedia di dalam kamar tidur homestay. Ketersediaan fasilitas di dalam kamar tidur homestay dan fasilitas tersebut dapat

Tabel 7.

Pengelolaan Kebersihan dan/atau Sanitasi

\begin{tabular}{|c|c|c|c|c|}
\hline \multirow{2}{*}{ Pengelolaan Kebersihan dan/atau Sanitasi } & \multicolumn{3}{|c|}{ Kondisi } & \multirow{2}{*}{ - Jumlah Homestay } \\
\hline & Baik & Cukup Baik & Kurang Baik & \\
\hline Kamar & 3 & 14 & 0 & 17 \\
\hline Kamar Mandi & 11 & 6 & 0 & 17 \\
\hline Pengelolaan Limbah Padat & 14 & 0 & 3 & 17 \\
\hline Pengelolaan Limbah Cair & 17 & 0 & 0 & 17 \\
\hline
\end{tabular}

Sumber: Data Primer, 2018

Pemilik homestay sudah cukup mengetahui pengelolaan kebersihan/sanitasi untuk homestay, dilihat dari kondisi kamar dan rumah yang sudah cukup baik, kondisi kamar mandi, berfungsi dengan baik merupakan salah satu hal yang dapat meningkatkan kenyamanan wisatawan untuk tinggal di homestay. 
Tabel 8.

Ketersediaan Fasilitas di dalam Kamar Tidur Homestay Aktif

\begin{tabular}{lllll}
\hline \multirow{2}{*}{ Jenis Fasilitas } & \multicolumn{3}{c}{ Kondisi Fasilitas } & \\
\cline { 2 - 4 } & $\begin{array}{c}\text { Tersedia dan } \\
\text { berfungsi baik }\end{array}$ & $\begin{array}{c}\text { Tersedia namun } \\
\text { tidak berfungsi }\end{array}$ & Tidak Tersedia & Jumlah Homestay \\
\hline AC & 2 & 0 & 15 & $\mathbf{1 7}$ \\
Kipas Angin & 12 & 1 & 4 & $\mathbf{1 7}$ \\
Meja Kecil & 15 & 0 & 2 & $\mathbf{1 7}$ \\
Kursi & 16 & 0 & 1 & $\mathbf{1 7}$ \\
Almari Pakaian & 8 & 0 & 9 & $\mathbf{1 7}$ \\
Single/Double Bed & 17 & 0 & 0 & $\mathbf{1 7}$ \\
Bantal/Guling & 17 & 0 & 0 & $\mathbf{1 7}$ \\
Selimut & 17 & 0 & 0 & \\
\hline
\end{tabular}

Sumber: Data Primer, 2018

Berdasarkan Tabel 8, dapat diketahui bahwa mayoritas homestay menyediakan beberapa jenis fasilitas yang masih berfungsi dengan baik, seperti kipas angin, meja kecil, kursi, tempat tidur, bantal/guling, serta selimut. Mayoritas pemilik homestay belum menyediakan AC sebagai salah satu jenis fasilitas yang ada di dalam kamar tidur homestay. Almari pakaian tidak tersedia di 9 (Sembilan) homestay, tetapi masih tersedia dan berfungsi dengan baik di 8 (delapan) homestay. $\mathrm{NrH}$ menyampaikan sebagai berikut.

"Fasilitas yang ada di homestay ya meja, kipas. Fasilitas lain yang bisa dipakai wisatawan paling ruang buat belajar mbatik aja."

Hampir sama dengan apa yang disampaikan $\mathrm{NrH}$, menurut Why

"Fasilitas homestay ada almari, kipas angin, meja, alas untuk tidur, yang dipan ada, yang di lantai ada."

Mengapa menyediakan kamar homestay dengan fasilitas seperti kipas angin, almari, meja, dan alas tidur. Hal itu disiapkan untuk memenuhi kebutuhan wisatawan.

Sementara menurut GsB:

"Satu kamar ya cuma satu tempat tidur, tapi bisa untuk berdua. Fasilitas di dalam kamar ada tempat tidur, bantal, kursi, ada cermin, dan juga ada almari."

GsB menyampaikan bahwa satu kamar yang ada di homestay, terdiri dari tempat tidur, bantal, kursi, cermin, dan almari yang masih berfungsi dengan baik. Wisatawan yang menginap kadang lebih dari satu hari, sehingga diperlukan almari untuk menyimpan baju wisatawan.

Pengetahuan mengenai pengelolaan fisik dan lingkungan, meliputi pengelolaan fasilitas dan kebersihan juga perlu didukung oleh sumber daya manusia pengelola homestay. SDM pengelola homestay yang mumpuni akan dengan mudah mengelola homestay. Perlu juga diketahui pengetahuan tentang pengelolaan SDM, kelembagaan, dan data pada homestay aktif. Pengelolaan SDM yang dimaksud dalam tulisan ini meliputi ketersediaan karyawan, nama homestay, dan struktur organisasi.

Tabel 9.

Ketersediaan Karyawan, Nama Homestay, dan Struktur Organisasi

\begin{tabular}{llllll}
\hline \multirow{2}{*}{\multicolumn{1}{c}{ Keterangan }} & \multicolumn{3}{c}{ Kondisi } & \multirow{2}{*}{ Jumlah Homestay } \\
\cline { 2 - 5 } & & Baik & Cukup Baik & Kurang Baik & 17 \\
\hline Karyawan & 0 & 1 & 16 & $\mathbf{1 7}$ \\
Nama Homestay & 6 & 0 & 11 & $\mathbf{1 7}$ \\
Struktur Organisasi & 0 & 0 & 17 & \\
\hline
\end{tabular}


Berdasarkan observasi, ada satu pemilik yang sudah mempekerjakan tetangganya untuk membantu mengelola homestay. Mtm menyampaikan bahwa ada yang dipekerjakan di homestay untuk membantu mengurus keperluan wisatawan.

"Ada, tetep ada karena kalau tamu minta makan itu, kami sudah tidak bingung, karena istri kan kerja."

Mayoritas pemilik homestay belum memiliki karyawan tetap yang membantu dalam pengelolaan homestay. $\mathrm{NrH}$ menuturkan bahwa belum mempekerjakan tetangga atau orang lain karena belum banyak kamar yang dimiliki.

Belum tersedianya karyawan yang membantu pengelolaan homestay dikarenakan masih belum banyak wisatawan yang rutin menginap di homestay. Pengelolaan SDM yang masih minim tersebut juga dipengaruhi oleh belum adanya lembaga atau organisasi yang khusus mengelola homestay di Desa Wisata Wukirsari. Apabila sudah tersedia kelembagaan yang khusus menangani homestay, diasumsikan akan lebih merata dalam menempatkan wisatawan di homestay warga masyarakat. Maka dari itu, dapat dipersiapkan tenaga atau karyawan yang dibutuhkan dalam mengelola homestay dan mengurusi kebutuhan wisatawan selama menginap di homestay. $\mathrm{NrH}$ menyampaikan bahwa memang belum ada organisasi yang fokus menangani homestay, tetapi ada orang yang dianggap pemimpin homestay di Desa Wisata Wukirsari.

"Nah ini ya kalau sementara ya baru bu Erni, karena beliau yang sudah lebih awal. Dia mengawali rumahnya boleh untuk kegiatan, tapi untuk komunitasnya memang belum, dan ini di tahun ini kami merintis untuk bisa menjadi suatu ikatan homestay. Kalau ketertarikan warga sudah, cuma kan istilahnya belum secara maksimal untuk bisa berkumpul terus, paling baru jadi satu di paguyuban batik. Jadi rembugannya ya masih nimbrung di desa wisata dan paguyuban batik. Kalau yang komunitas sendiri khusus homestay belum ada."

\section{Ltd juga menuturkan:}

"Belum, organisasi homestay belum ada, baru pokdarwis, ada yang memang kelompok dari gazebo (paguyuban batik), kalau yang khusus mengurusi homestay belum ada."

Pengelolaan SDM dan kelembagaan juga perlu didukung oleh kegiatan pelatihan atau studi banding para pemilik homestay. Pelatihan atau studi banding diperlukan untuk menambah wawasan pemilik homestay tentang bagaimana cara mengelola homestay, menata kamar, menyajikan makanan kepada para wisatawan, dan lain sebagainya.

Pelatihan atau studi banding belum diikuti oleh 11 pemilik homestay. Empat orang pemillik homestay pernah mengikuti pelatihan sebanyak satu kali dan 2 (dua) orang pemilik homestay sudah mengikuti pelatihan lebih dari satu kali. Pelatihan atau studi banding yang belum diikuti pemilik homestay dapat berpengaruh terhadap pengelolaan homestay di desa wisata Wukirsari.

$\mathrm{NrH}$ menyampaikan bahwa beliau beberapa kali pernah mengikuti pelatihan atau studi banding terkait homestay.

"Kalau saya sendiri pernah [ikut pelatihan atau studi banding], untuk teman-teman yang lain mungkin belum. Pelatihannya pernah di Tembi, di hotel di Jogja, karena sebenarnya di DIY ada asosiasi homestay juga. Ketuanya mas Dodo dari Pentingsari. Kalau di Pentingsari kan menginapnya sudah satu grup sekolah, kalau disini kebanyakan pribadi. Kaya di Nglanggeran live in sekolah-sekolah, pengelolanya mas Aris, mas Sugeng."

Lain halnya dengan MNs, beliau mengatakan belum pernah mengikuti pelatihan homestay.

"Belum pernah saya ikut pelatihan homestay.
Saya kalau pelatihan-pelatihan itu.. orangnya
belum pernah dilatih. Pelatihan satu tentang
pengelolaan sampah itu kayanya. Setelah dilatih
kaya yakyak o, setelah satu minggu sudah pudar.
Kembali seperti semula."

Menurut Mrh, beliau sudah pernah mengikuti studi banding tentang homestay ke beberapa penginapan baik di Yogyakarta maupun di luar Yogyakarta.

"Studi banding sama Bu Sita tahun 2017, ke Candirejo, Omkara Resort, dan Kulonprogo. Hampir sama dengan di Giriloyo cuma lebih sejuk." 
Berdasarkan pencarian data yang dilakukan, studi banding tentang homestay tersebut dilaksanakan oleh Universitas Gadjah Mada melalui Program Pengabdian Kepada Masyarakat Berbasis Pengembangan Desa Binaan Departemen Arsitektur dan Perencanaan Fakultas Teknik UGM Tahun 2017. Lokasi studi banding ke Omkara Resort yang berada di Kabupaten Sleman, ke salah satu desa wisata di Kulonprogo, serta ke Desa Wisata Candirejo dekat Candi Borobudur. Studi banding dilakukan untuk pembinaan dan pengembangan SDM masyarakat di Desa Wisata Wukirsari khususnya para pemilik homestay. Studi banding dilakukan untuk menambah wawasan beberapa pemilik homestay yang ada di Desa Wisata Wukirsari.

Tabel 10.

Pelatihan/Studi Banding

\begin{tabular}{ll}
\hline \multicolumn{1}{c}{ Pelatihan / Studi Banding } & $\begin{array}{c}\text { Jumlah } \\
\text { Homestay }\end{array}$ \\
\hline $\begin{array}{l}\text { Pemilik homestay mengikuti } \\
\text { pelatihan lebih dari 1 kali }\end{array}$ & 2 \\
$\begin{array}{l}\text { Pemilik homestay mengikuti } \\
\text { pelatihan } 1 \text { kali }\end{array}$ & 4 \\
$\begin{array}{l}\text { Pemilik homestay belum pernah } \\
\text { melakukan pelatihan/studi } \\
\text { banding }\end{array}$ & 11 \\
\hline Jumlah Total & 17 \\
\hline
\end{tabular}

Sumber: Data Primer, 2018
Pengelolaan SDM dan kelembagaan akan semakin baik apabila didukung pula dengan ketersediaan data yang dimiliki oleh pemilik homestay. Data tentang pemilik homestay, data homestay, data keuangan/administrasi, data wisatawan yang pernah menginap, dan standarisasi harga sangat diperlukan. Ketersediaan data yang mudah diakses akan mempermudah wisatawan dalam memilih homestay yang sesuai dengan kebutuhan mereka.

Data juga biasanya dibutuhkan oleh akademisi, instansi pemerintah, maupun pihak swasta yang ingin mengetahui tentang kondisi homestay di desa wisata. Berdasarkan hasil penelitian, hanya 1-2 orang pemilik homestay yang sudah memiliki pengelolaan data yang baik/cukup baik.

Menurut penuturan MNs, beliau belum memiliki data tertulis baik tentang pemilik homestay, homestay, dan wisatawan yang pernah menginap. Beliau merasa apabila ada wisatawan menginap namun uang dari pendapatan homestay belum banyak. Beliau merasa ribet untuk mencatat pemasukan dan pengeluaran dari usaha homestay.

"Nggak pernah ditulis, saya ribet nanti lihat tamu sekian kok uangnya tidak ada. Misal saya dapat tamu sekian, nanti feenya 10\%, mugkin coba saya tulis, tapi saya ribet, pusing. Tiba-tiba uangnya tidak ada kemana ya?"

Tabel 11. Pengelolaan Data

\begin{tabular}{llllll}
\hline \multirow{2}{*}{\multicolumn{1}{c}{ Pengelolaan Data }} & \multicolumn{3}{c}{ Kondisi Homestay } & \multirow{2}{*}{ Jumlah Homestay } \\
\cline { 2 - 5 } & & Baik & Cukup Baik & Kurang Baik & \\
\hline Data Pemilik Homestay & 1 & 2 & 14 & 17 \\
Data Homestay & 1 & 2 & 14 & 17 \\
Data Keuangan/Administrasi & 0 & 1 & 16 & 17 \\
Data Wisatawan & 2 & 1 & 14 & 17 \\
Standarisasi Harga & 1 & 13 & 3 & 17 \\
\hline
\end{tabular}

Sumber: Data Primer, 2018

Pengelolaan data yang masih kurang baik tersebut juga berbanding lurus dengan pengelolaan promosi. Pemilik homestay belum melakukan promosi secara maksimal. Promosi dibutuhkan agar masyarakat luas mengetahui keberadaan homestay di desa wisata. Penge- tahuan tentang Pengelolaan Promosi masih kurang dimiliki para pemilik homestay. Promosi melalui website, brosur, media sosial, word of mouth atau getok tular, dan kerjasama dengan pihak lain belum sering dilakukan oleh pemilik homestay. Hanya ada satu yang sudah aktif di 
mempromosikan melalui media sosial dan sudah bergabung dengan platform booking. com.

Menurut pendapat Ftr, beliau belum melakukan promosi secara pribadi untuk memasarkan homestay miliknya karena merasa belum layak untuk dipromosikan.

"Ya itu tadi, kita masih tergantung pada promosi, kan promosi tergantung pengelola gazebo (paguyuban batik atau pokdarwis), sementara dari kami belum ada usaha mempromosikan dari kami sendiri, karena saya pikir homestay kami belum layak untuk dipromosikan, seperti itu."

Mtm menyampaikan bahwa dirinya belum mempromosikan homestay menggunakan brosur, tetapi sudah bergabung dengan booking. com untuk mempromosikan homestay miliknya.

"Belum promosi menggunakan brosur. Di
internetnya juga belum maksimal, kalau di sini
kan baru saya sendiri yang [ikut] di booking.com,
lainnya belum. Yo karena masih malas-malasan,
pilih masih pengen merdeka, itu saja."

Tabel 12.

Pengelolaan Promosi

\begin{tabular}{lllll}
\hline \multirow{2}{*}{ Media Promosi } & \multicolumn{3}{c}{ Kondisi } & Aktif dan \\
\cline { 2 - 4 } & $\begin{array}{c}\text { diperbarui } \\
\text { datanya }\end{array}$ & $\begin{array}{c}\text { Pasif/Kadang- } \\
\text { kadang/tidak } \\
\text { diperbarui datanya }\end{array}$ & $\begin{array}{c}\text { Tidak tersedia/ } \\
\text { tidak dilakukan }\end{array}$ & $\begin{array}{c}\text { Jumestay } \\
\text { Homestan }\end{array}$ \\
\hline Website & 0 & 0 & 17 & 17 \\
Brosur & 0 & 0 & 17 & 17 \\
Media Sosial & 1 & 0 & 16 & 17 \\
Word of Mouth atau Getok Tular & 0 & 2 & 15 & 17 \\
Kerjasama dengan pihak lain & 1 & 1 & 15 & 17 \\
\hline
\end{tabular}

Sumber: Data Primer, 2018

\section{Pengelolaan Homestay}

Pengelolaan homestay di Desa Wisata Wukirsari terdiri dari dua pola, yaitu omahku saanané (rumahku seadanya) dan omahku nyeni (rumahku nyeni). Pola pengelolaan homestay omahku saanané adalah pola pengelolaan homestay yang masih seadanya atau sederhana, pemilik homestay masih memiliki rencana ke depan terkait dengan pengelolaan homestay, baik penambahan fasilitas, perbaikan fasilitas, dan lain sebagainya.

Omahku nyeni berasal dari kata seni, dan digunakan untuk penyebutan pola pengelolaan ini, karena rumah yang dijadikan homestay memiliki keindahan dan keunikan. Seni itu bebas, hal itu juga menggambarkan kreativitas pemilik homestay dalam mengembangkan homestaynya. Pola pengelolaan homestay omahku nyeni adalah pola pengelolaan homestay yang sudah maju, sudah ada pembagian kerja, fasilitas lengkap, terdapat data buku tamu/wisatawan yang pernah menginap, pengetahuan pemilik homestay tentang penyelenggaraan homestay sudah baik, pernah mengikuti pelatihan homestay, ada kemauan untuk mengembangkan homestay baik fisik, maupun administrasi, serta kondisi homestay yang bersih. Omahku Nyeni juga berarti rumah yang memiliki keindahan dan kenyamanan serta menimbulkan rasa senang atau bahagia bagi orang lain. Omahku nyeni juga tetap memiliki kekurangan, antara lain jumlah kamar yang tidak banyak untuk menginap wisatawan, ada homestay yang lokasinya berada tidak satu rumah dengan pemilik.

Secara umum kondisi rumah yang dijadikan homestay apa adanya atau yang dalam bahasa Jawa, saanané. Seperti yang disampaikan oleh Dld,

“...untuk tempat tidurnya seadanya dulu. Kalau yang mewah seperti hotel, belum mampu, apa adanya seperti ini. Bisa survey dulu, mau atau tidak."

Omahku saanané memiliki pola pengelolaan fisik dan lingkungan yang cukup 
baik, pengelolaan data yang cukup baik dan/atau rendah, pengelolaan SDM dan Kelembagaan cukup baik dan/atau rendah serta Pengelolaan Promosi cukup baik dan/ atau rendah. Pola pengelolaan Omahku Saanané memiliki kelebihan dan kekurangan. Kelebihannya adalah, salah satu homestay memiliki fasilitas yang cukup baik, seperti tersedianya AC, kamar mandi dengan toilet duduk. Kekurangannya adalah kondisi kamar dan homestay yang kurang tertata rapi dan kurang bersih, serta fasilitas lain yang belum tersedia. Selain itu ada salah satu homestay yang lokasinya dekat dengan kandang hewan ternak. Kekurangan lain adalah ada homestay yang sama sekali belum pernah menerima kunjungan wisatawan. Pengelolaan data dan promosi masih minim dilakukan oleh pemilik homestay. Pola pengelolaan homestay Omahku Saanané dapat ditemui pada homestay milik Dld, StF, Bsk, Mrt, Rsn, Mrh, StC, MNs, Why, Slm, Ltd, Shd, Bkh, dan Ftr.

Pola pengelolaan homestay Omahku Nyeni terdiri dari aspek pengelolaan fisik dan lingkungan yang sangat baik, pengelolaan data yang sangat baik, cukup baik dan/atau rendah, pengelolaanSDM dan Kelembagaan sangat baik serta Pengelolaan Promosi cukup baik dan/ atau rendah. Hal tersebut dipengaruhi oleh faktor-faktor yang memengaruhi pengelolaan homestay yang sangat baik. Pola pengelolaan homestay Omahku Nyeni dapat ditemui pada homestay milik GsB, NrH, dan Mtm.

\section{SIMPULAN}

Persepsi pemilik homestay tentang homestay mayoritas sudah diketahui. Namun ternyata hal tersebut belum mempengaruhi pengelolaan homestay yang sesuai dengan pedoman pengelolaan homestay berdasarkan ASEAN Homestay Standard maupun pedoman pengelolaan homestay yang dibuat oleh pemerintah Indonesia. Mayoritas pemilik homestay masih melakukan pola pengelolaan Omahku Saanané atau masih mengelola homestay secara sederhana. Mayoritas pemilik homestay belum mengetahui cara mengelola homestay pada aspek fisik dan lingkungan, aspek SDM, kelembagaan, dan data, serta aspek promosi.
Saran yang dapat dilakukan untuk mengelola dan mengembangkan homestay di Desa Wisata Wukirsari antara lain dengan menyelenggarakan sosialisasi Pedoman Pengelolaan Homestay kepada seluruh pemilik homestay. Selain itu juga dapat dilakukan pelatihan tentang homestay dan pengelolaannya secara rutin yang diikuti semua pemilik homestay. Hal tersebut dimaksudkan agar pemilik homestay dapat mengelola homestay sesuai standar dan membuat wisatawan merasa nyaman tinggal lebih lama di desa wisata Wukirsari.

\section{DAFTAR PUSTAKA}

Ahimsa-Putra, H.S. (2011). "Pariwisata di Desa dan Respon Ekonomi: Kasus Dusun Brayut di Sleman, Yogyakarta." Patrawidya, 12(4): 635-660.

ASEAN Secretariat. (2016). ASEAN Homestay Standard. Jakarta: ASEAN Secretariat

Denzin, N.K. Dan Lincoln, Y.S (ed). (2009). Handbook of Qualitative Research. Edisi kedua. Diterjemahkan oleh Dariyatno, dkk. Yogyakarta: Pustaka Pelajar.

Feldman, R.S. 2009. Essentials of Understanding Psychology Ninth Edition. New York: McGraw-Hill.

Gunawan, D.E.K, dan Prijadi, R. (2011). "Reaktualisasi Ragam Art Deco dalam Arsitektur Kontemporer." Media Matrasain, 8(1):68-81.

$\mathrm{Hu}$, Y., Wang, J., dan Wang, R. (2012). "Evaluating the Performance of Taiwan Homestay Using Analytic Network Process." Mathematical Problems in Engineering, 2012(1):1-24

Ibrahim, Y. Dan Razzaq, A.R. (2010). "Homestay Program and Rural Community Development in Malaysia." Journal of Ritsumeikan Social Sciences and Humanities, 2:7-24.

Kayat, K. (2010). “The Nature of Cultural Contribution of A Community-Based Homestay Programme." Tourismos: 
An International Multidisciplinary Journal of Tourism, 2(2): 145-159.

Lynch, P. (2005). “Sociological Impressionism in a Hospitality Context." Annals of Tourism Research, 32(3): 527-548.

Page, S.J. (2007). Tourism Management. Oxford: Butterworth-Heinemann.

Robbins, S.P dan Couter, M. (2009). Management Tenth Edition. New Jersey: Pearson Education, Inc.
Sugiyono. (2016). Metode Penelitian Kombinasi (Mix Methods). Bandung: CV Alfabeta. Bandung.

Tyas, L.A.N. (2009). Eco-Friendly Homestay Management in Ubud Area, Bali Province. Yogyakarta: Graduate School Gadjah Mada University.

Widiastuti, I. (2014). “Transformasi Makna pada Arsitektur Asli Daerah dalam Tampilan Visual Arsitektur." Seminar Rumah Tradisional-PUSKIM, 15:1-16. 